\title{
Herpes Simplex Virus 2 IgM Antibody Measurement
}

National Cancer Institute

\section{Source}

National Cancer Institute. Herpes Simplex Virus 2 IgM Antibody Measurement. NCI

Thesaurus. Code C98739.

The determination of the amount of herpes simplex virus $2 \lg \mathrm{M}$ antibody present in a sample. 